\title{
EFFECT OF ADDITION OF HERBS ON BODY WEIGHT AND ASSESSMENT OF PHYSICAL AND CHEMICAL ALTERATIONS IN THE TIBIA BONES OF BROILER CHICKENS
}

\author{
Małgorzata Kwiecień, Anna Winiarska-Mieczan \\ Department of Nutrition \\ University of Life Sciences in Lublin
}

\begin{abstract}
Bones, even after their growth has been completed, react to both external and internal factors which include feeding. The process of bone mineralization, including limb bones, is a very important index of the effectiveness and quality of feeding procedures, aswell as a measure of the organism's health status. Antibiotics, which used to be very popular growth stimulators in feeding, have recently been replaced with natural feed additives, namely herbs. Although the usefulness of herbs has been known for a long time, little information has been found so far concerning their use in animal feeding and effect on the physical parameters and the chemical composition of the bones chickens.

The aim of the present work was to determine a potential influence of herbs added to chickens' diets on the body weight, chosen physical parameters of tibia bones: their weight, length and the content of the basic mineral components of the bone.

The experiment was conducted on 210 broiler chickens of the Ross 308 line, divided into seven feeding groups: the control group (I - a mixture containing an antibiotic) and six experimental ones (II - hops, III - lime, IV - lemon balm, V - pansy, VI - peppermint, VII - nettle). In the bone samples, their weight, length, and the chemical composition of ash: $\mathrm{Ca}, \mathrm{Mg}$ and $\mathrm{P}$ were determined.

The results obtained in the present study reveal that an addition of nettle or lemon balm to the mixtures led to an increase in the body weight of broiler chickens. An addition of hops (II) to the mixtures led to a decrease in the length of the bones. An addition of lemon balm, pansy, peppermint or nettle to the mixtures had a negative effect on the level of $\mathrm{Mg}$ in the bones.
\end{abstract}

Key words: broiler chicken, herb, tibia bones, physical and chemical parameters.

dr Małgorzata Kwiecień, Department of Nutrition, University of Life Sciences in Lublin, Akademicka 13, 20-950 Lublin, Poland, e-mail: malgorzatakwiecienar@wp.pl 


\title{
WPŁYW DODATKU ZIÓŁ DO PASZY NA MASE CIAŁA ORAZ CECHY FIZYCZNE I CHEMICZNE KOŚCI PISZCZELOWYCH KURCZĄT BROJLERÓW
}

\begin{abstract}
Abstrakt
Kości, nawet po zakończeniu swego wzrostu, reagują na czynniki wewnętrzne i zewnętrzne, do których należy również żywienie. Proces mineralizacji tkanki kostnej, w tym kości kończyn, jest bardzo ważnym wskaźnikiem efektywności i jakości stosowanego żywienia, ale również i miernikiem stanu zdrowotnego organizmu. Antybiotyki, do niedawna popularne $\mathrm{w}$ żywieniu stymulatory wzrostu, zaczęto zastępować naturalnymi dodatkami paszowymi, np. ziołami. Mimo że przydatność ziół jest znana od dawna, to w żywieniu zwierząt, jak dotąd, nie ma jednoznacznych informacji na temat ich wpływu na organizm kurcząt oraz parametry fizyczne i skład chemiczny kości.

Celem pracy było określenie potencjalnego wpływu dodatku ziół do mieszanek paszowych na masę ciała, wybrane parametry fizyczne kości piszczelowych: masę i długość oraz zawartość podstawowych mineralnych składników kośćca.

Doświadczenie przeprowadzono na 210 kurczętach brojlerach Ross 308, podzielonych na 7 grup: kontrolna (I - antybiotyk) i 6 doświadczalnych (II - chmiel, III - lipa, IV - melisa, V - bratek, VI - mięta, VII - pokrzywa). Określono masę powietrznie suchą kości piszczelowych, długość całkowitą, a po mineralizacji - zawartość podstawowych składników mineralnych: $\mathrm{Ca}, \mathrm{Mg}$ i $\mathrm{P}$.

Stwierdzono, że wprowadzenie do mieszanek pokrzywy i melisy istotnie zwiększyło masę ciała kurcząt, a dodatek chmielu spowodował skrócenie kości. Zastosowanie dodatku melisy, bratka, mięty i pokrzywy wpłynęło na zmniejszenie koncentracji $\mathrm{Mg}$ w kościach.
\end{abstract}

Słowa kluczowe: kurczęta brojlery, zioła, kości piszczelowe, parametry fizyczne i chemiczne.

\section{INTRODUCTION}

The chemical composition of each organism is relatively fixed and determined by its genotype. Maintaining the composition on a fixed level, due to homeostasis, is essential for all tissues, including bones. Bones, even after their growth has been completed, react to both external and internal factors, which include feeding. With respect to the practice of poultry feeding, the process of bone mineralization, including limb bones, is a very important index of the effectiveness and quality of feeding procedures, as well as a measure of the organism's health status (FerReTti et al. 1993, Śliwa and RAdZKi 1995, Kwiecień 1997, 1999, RAth et al. 2000, CRespo et al. 2000, JANoCHA et al. 2004, KWIECIEŃ 2005).

Chickens are characterized by a fast growth rate. The mixtures used in nutrition of chickens are expected to have a high concentration of protein, energy, vitamins and minerals supplemented with stimulators (ZIMNOCH et al. 2000).

The conditions of broiler breeding and management, as well as genetic selection aimed at reaching a high body weight at the quickest rate possible, have resulted in higher requirements regarding mechanical bone resistance in chickens. The burden put on the bones, resulting from a high body 
weight conditioned mainly by the muscles of breasts and limbs, the imbalance between these parts of the body and an excessive ratio between the muscle weight and bone weight lead to structural deformities and distortions of the skeleton, which in most cases affect the limbs (CRESPO et al. 1999).

Recently, antibiotics which used to be very popular growth stimulators in feeding (FRITZ et al. 1993, Guo et al. 2003, DEMIR et al. 2005), have been replaced with natural feed additives, namely herbs (CRAIG 1999, KALOREY et al. 2005). This was caused by the concerns regarding an unwanted influence of antibiotics on man as a consumer, as well as on the environment (DonoGHUE 2003).

Herbs possess healing properties and they reinforce the immune system. They influence physiological processes and contribute some nutritive value. Consequently, they can affect directly or indirectly the production results (CRAig 1999, Nageswara et al. 1999, Hota et al. 2000, Cross et al. 2004, Guo et al. 2004, Mitsch et al. 2004). Although the usefulness of herbs has been known for a long time, little information has been found so far concerning animal feeding and the remains of certain substances in the tissues, their influence on the organism or the animal products obtained. The knowledge concerning the influence of herbs on the physical parameters and the chemical composition of the bones is also scarce (KWIECIEN, WINIARSKA-MIECZAN 2007), which makes it impossible to verify most of the authors' own studies and induces their continuation.

The aim of the present work was to determine a potential influence of herbs added to chickens' diets on the body weight and chosen physical parameters of tibia bones: their weight, length and the content of the basic mineral components of the bone: $\mathrm{Ca}, \mathrm{P}$ and $\mathrm{Mg}$.

\section{MATERIAL AND METHODS}

The experiment was conducted on 210 broiler chickens of the Ross 308 line, reared in boxes under standard environmental conditions until they were 42 days old. One-day-old chickens were randomly divided into 7 groups: a control group (I) and six experimental groups (II, III, IV, V, VI and VII). Each group consisted of 30 birds in three replications.

From raising day 1 to day 10, the birds were administered a starter mixture (S), from day 11 to day 35 - a grower mixture (G) and from day 36 to day 42 - a finisher mixture (F). The control mixtures contained: maize, soybean meal, dried grass silage, soybean oil and antibiotic (Flavomycin). Composition and nutritive value of the control and experimental mixtures are presented in Table 1 . In the experimental mixtures, dried grass silage was replaced by $2 \%$ addition of dried herbs: hops (Humulus lupulus L.), lime 
Table 1

Composition (\%) and nutritive value of the mixtures

\begin{tabular}{|c|c|c|c|c|}
\hline \multirow{3}{*}{ Item } & \multicolumn{2}{|c|}{$\mathrm{S}$} & \multicolumn{2}{|c|}{$\mathrm{G} / \mathrm{F}$} \\
\hline & \multicolumn{4}{|c|}{ groups } \\
\hline & $I^{*}$ & II-VII & $I^{*}$ & II-VII \\
\hline Maize & 55.15 & 55.5 & 57.78 & 57.78 \\
\hline Soybean meal $46 \%$ & 33.0 & 33.0 & 30.0 & 30.0 \\
\hline Yeast & 2.0 & 2.0 & 2.0 & 2.0 \\
\hline Dried grass silage meal & 2.0 & - & 2.0 & - \\
\hline Herbal meal & - & 2 & - & 2 \\
\hline Soya oil & 3.0 & 3.0 & 4.0 & 4.0 \\
\hline Dicalcium phosphate & 1.5 & 1.5 & 1.2 & 1.2 \\
\hline Limestone & 1.5 & 1.5 & 1.5 & 1.5 \\
\hline $\mathrm{NaCl}$ & 0.5 & 0.5 & 0.35 & 0.35 \\
\hline DL-methionine & 0.15 & 0.15 & 0.15 & 0.15 \\
\hline L-lysine & 0.2 & 0.2 & 0.02 & 0.02 \\
\hline Vitamin-mineral premix ${ }^{a}$ & 1.0 & 1.0 & 1.0 & 1.0 \\
\hline Total & 100 & 100 & 100 & 100 \\
\hline \multicolumn{5}{|l|}{$1 \mathrm{~kg}$ feed mixtures contains: } \\
\hline $\mathrm{ME}(\mathrm{MJ})$ & 12.74 & 12.73 & 13.03 & 13.03 \\
\hline Crude protein $(\mathrm{g})$ & 214.1 & 214.1 & 194.2 & 194.2 \\
\hline Crude fibre (g) & 34.3 & 34.3 & 33.3 & 33.3 \\
\hline $\mathrm{Ca}(\mathrm{g})$ & 10.18 & 10.18 & 9.47 & 9.47 \\
\hline P total $(\mathrm{g})$ & 6.97 & 6.97 & 6.29 & 6.29 \\
\hline $\mathrm{Mg}(\mathrm{g})$ & 1.94 & 1.94 & 1.72 & 1.72 \\
\hline Lysine (g) & 12.12 & 12.12 & 9.98 & 9.98 \\
\hline Met + Cys (g) & 7.77 & 7.77 & 7.71 & 7.71 \\
\hline
\end{tabular}

I - control group; II-VII - experimental groups; S - starter mixture; G/F - grower/finisher mixture group

${ }^{a}$ Composition of premix starter/kg: vit. A $1360000 \mathrm{IU}$, vit. $\mathrm{D}_{3} 325000 \mathrm{IU}$, vit. E $4000 \mathrm{mg}$, vit. K3 $250 \mathrm{mg}$, vit. $\mathrm{B}_{1} 200 \mathrm{mg}$, vit. $\mathrm{B}_{2} 600 \mathrm{mg}$, vit. $\mathrm{B}_{6} 300 \mathrm{mg}$, vit. $\mathrm{B}_{12} 2000 \mu \mathrm{g}$, biotin $15 \mathrm{mg}$, folic acid $125 \mathrm{mg}$, nicotinic acid $3500 \mathrm{mg}$, D-calcium panthotenate $1200 \mathrm{mg}$, choline chloride 60000 mg, Mn 9000 mg, Cu 2000 mg, Zn 10000 mg, Fe 9000 mg, J 100 mg, Se 25 mg,

Co 70000 ug; Composition of premix grower/finisher/kg: vit. A 1200000 IU, vit. $\mathrm{D}_{3} 300000 \mathrm{IU}$, vit. E $3000 \mathrm{mg}$, vit. K3 $200 \mathrm{mg}$, vit $\mathrm{B}_{1} 150 \mathrm{mg}$, vit. $\mathrm{B}_{2} 500 \mathrm{mg}$, vit. $\mathrm{B}_{6} 250 \mathrm{mg}$, vit. $\mathrm{B}_{12} 1500 \mu \mathrm{g}$, biotin $10 \mathrm{mg}$, folic acid $100 \mathrm{mg}$, nicotinic acid $2500 \mathrm{mg}$, D-calcium panthotenate $1000 \mathrm{mg}$, choline chloride 60000 mg, Mn 9000 mg, Cu 2000 mg, Zn 10000 mg, Fe 9000 mg, J 100 mg, Se $25 \mathrm{mg}$, Co $70000 \mu \mathrm{g}$ *antibiotic Flavomycin $(0.1 \%)$ 
(Tilia cordata L.), lemon balm (Melissa officinalis L.), pansy (Viola tricolor L.), peppermint (Mentha piperita L.) or nettle (Urtica dioica L.). Since the beginning of broiler raising, the birds were fed in accordance with the methodical system presented in Table 2.

Table 2

Design of the experiment

\begin{tabular}{|c|l|}
\hline Group & \multicolumn{1}{|c|}{ Trestment } \\
\hline I (control) & antibiotic and dried grass silage $-2 \%$ \\
\hline II & hops $($ Humulus lupulus L. $)-2 \%$ \\
\hline III & lime (Tilia cordata L. $)-2 \%$ \\
\hline IV & lemon balm $($ Melissa officinalis L. $)-2 \%$ \\
\hline V & pansy (Viola tricolor L. $)-2 \%$ \\
\hline VI & peppermint $($ Mentha piperita L. $)-2 \%$ \\
\hline VII & nettle (Urtica dioica L. $)-2 \%$ \\
\hline
\end{tabular}

The mixtures were delivered in the form of a mass of pelets; only the nestlings were administered crumbles. Feed and water were provided ad libitum.

After weighing chickens on day 42,8 birds (4 cockerels and 4 hens) from each group, about the average weight, were sacrificed and subjected to dissection. During the dissection analysis, their tibia bones were taken for preparations according to the Polish method described by ZiołECKI and DoRUCHOWski (1989). The weight, length and percentage share of the bone in the total body weight were assessed.

After the incineration process at the temperature of $650^{\circ} \mathrm{C}$, crude ash and basic mineral components: $\mathrm{Ca}, \mathrm{Mg}$ and $\mathrm{P}$ were determined. Crude ash was determined by the AOAC method (1999). The spectrophotometric atomic absorption (SAA) method was used to assess the content of $\mathrm{Ca}$ and $\mathrm{Mg}$, while the amount of $\mathrm{P}$ was determined with the colorimetric method on a Helios Delta apparatus.

The results were subject to a statistical analysis, using Statistica Version 5, with ANOVA single-factor variance test, adopting 0.01 as significance level (StatSoft Inc 1995). Significance of differences between means was determined by Tukey's test.

\section{RESULTS AND DISCUSSION}

The addition of herbs to the mixtures led to a significant differentiation and an increase in the body weight of broiler chickens in the experimental groups, in comparison with the body weight of the control group birds (Table 3). A different opinion is presented by KRAWCZYK et al. (2000) and 


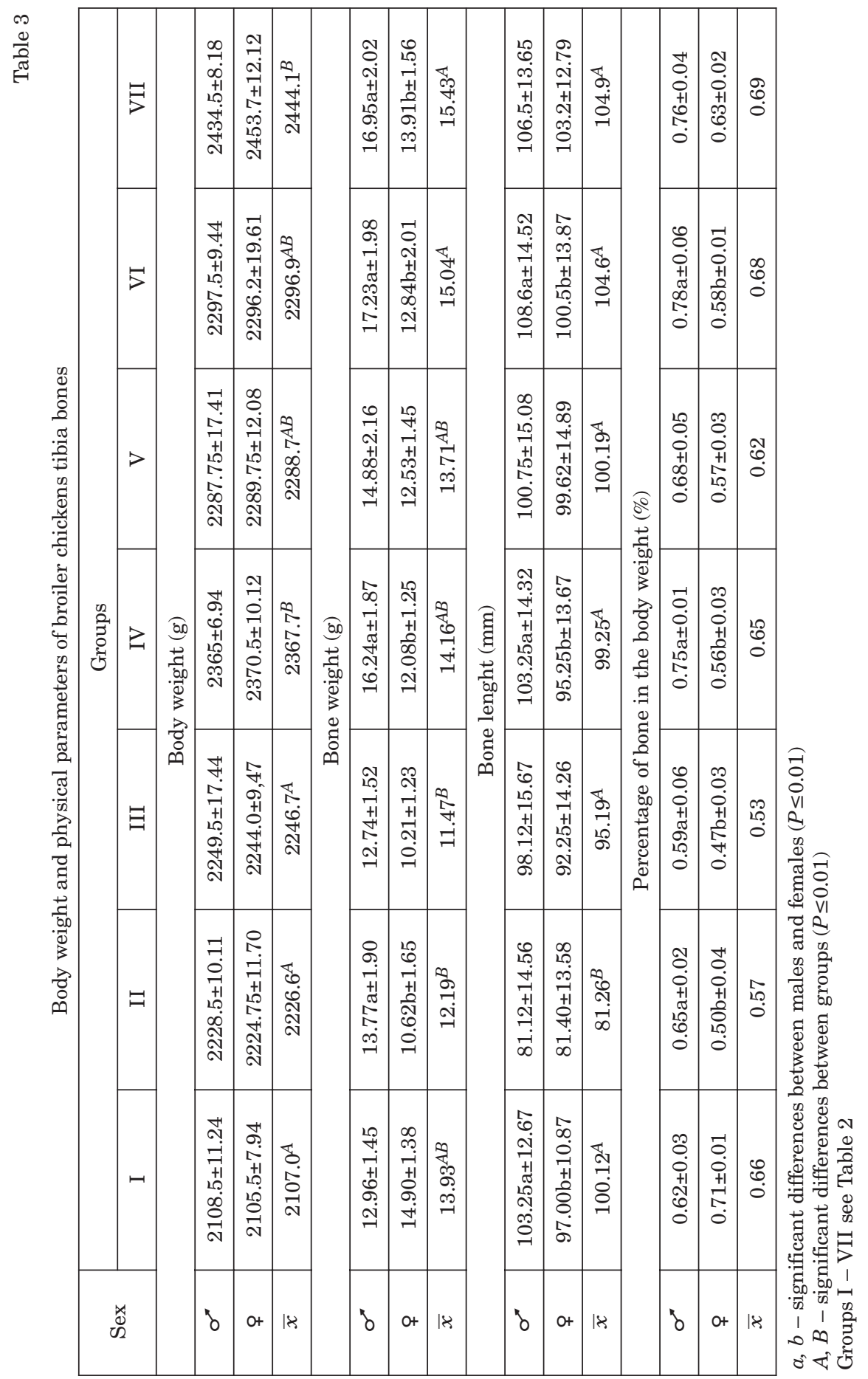


by Botsoglou et al. (2002; 2004), who obtained results suggesting a negative effect of herbs on the final body weight of broiler chickens.

The weight of the chickens' tibia bones was dependent on the sex of the birds, and thus, indirectly, on their bones weight, and it was statistically higher in cockerels than in hens in the groups receiving an addition of hops (II), lemon balm (IV), peppermint (VI) and nettle (VII).

An addition of hops (II) to the mixtures led to a decrease in the length of the bones in comparison with the control group. It was also noted that the bones of the cockerels were longer than the bones of the hens, and statistically significant differences regarding the length of the bones were observed between the roosters and hens administered an addition of antibiotic (I), lemon balm (IV) and peppermint (VI).

The results of the study concerning the weight and length of tibia bones coincide with the data quoted by KWIECIEN and WINIARSKA-MIECZAN (2007), who examined the femur as a representative bone in reference to the research concerning the skeletal system. The values of the physical parameters of the tibia bone examined in the authors' own studies are similar to the results observed by PisARski and KwIEcień (2003) and KwIECIEŃ (2003), yet the agents affecting the physical parameters of the bones were slightly different.

Introducing herbs into feeds for poultry did not lead to a differentiation in the percentage share of the bone in the total body weight. However, statistically significant differences were observed between the cockerels and hens receiving a supplement of hops (II), lime (III), lemon balm (IV) and peppermint (VI).

All physical parameters of the bones considered in the experiment were substantially higher in roosters than in hens, which, as suggested by BLENAU (1993), Śliwa and RADZKi (1995), SEEMAN (1999) and RATH et al. (1999), results from the systemic distinctness determined by sex and growth hormones.

The results of the studies performed by SzEREMETA et al. (2005) also indicate the influence of age and sex on bone parameters. The researchers found longer and heavier bones of larger diameter in male individuals. The results obtained in the authors' own studies suggest a positive effect of nettle on physical parameters of tibia bones in broiler chickens. A similar opinion is expressed in the studies by KwIEcIEN and WinIARSKA-MiEcZaN (2007).

One of the most serious problems in broiler raising is bone resistance, especially the resistance of the legs, which can be weakened by an inadequate composition of the feed mixture and may adversely influence the effectiveness of the production (CRESPO et al. 1999).

The herbs were not a factor that would significantly modify the content of calcium and phosphorus in the chickens' tibia bones (Table 4). The level of magnesium in the bones of the birds in the control group and the chickens administered mixtures with an addition of hops and lime was statistically significantly higher than its content in the bones of the chickens fed 


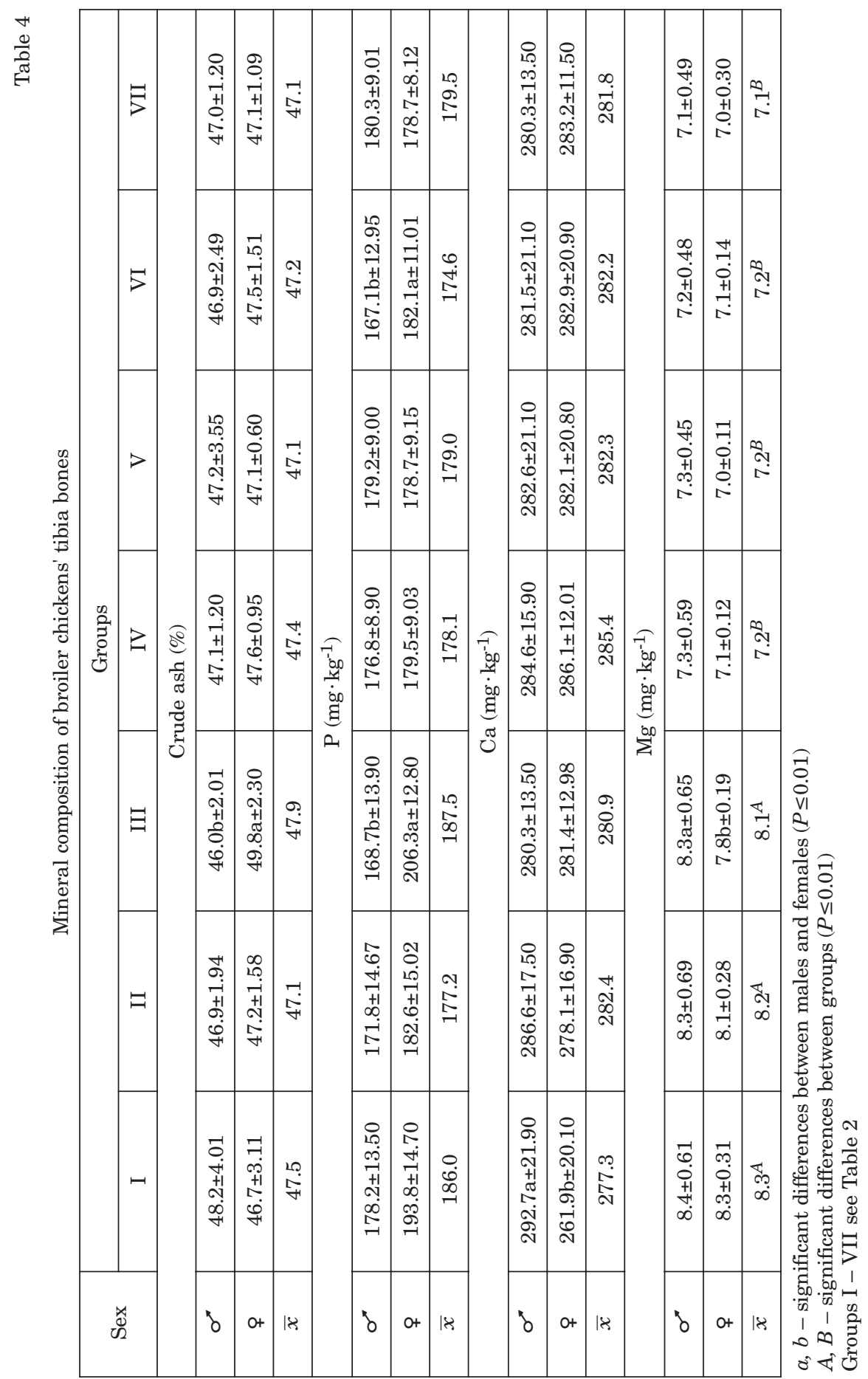


mixtures with a supplement of lemon balm, pansy, peppermint or nettle. Moreover, it was shown that the bones of the cockerels receiving a supplement of lime in the feed had a significantly higher level of magnesium than the bones of the hens.

The study has shown that the herbs added to the experimental mixtures had a positive effect on both the physical properties examined and the chemical composition of the tibia bones in broiler chickens, which is noteworthy regarding not only production results but also the welfare of the birds (PISARSKI, KwIEcień 2003). It can be observed that none of the herbs we tested had an unambiguous effect on the examined parameters of the bone, whereas in the study performed by KwIECIEN and WinIARSKA-MiEcZAN (2007) nettle had the strongest influence on the majority of the properties of chickens' femoral bones.

\section{CONCLUSIONS}

The results obtained in the present study reveal that an addition of nettle or lemon balm to the mixtures led to an increase in the body weight of broiler chickens. An addition of hops (II) to the mixtures led to an decrease in the length of the bones. An addition of lemon balm, pansy, peppermint or nettle to the mixtures indicated a negative effect on the level of $\mathrm{Mg}$ in the bones.

\section{REFERENCES}

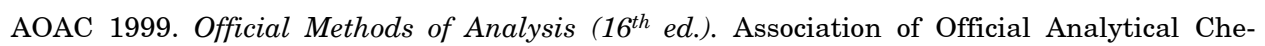
mist's, Arlington, VA.

Blenau B. 1993. The effects of sex factor in chicken on the rate of their skeletal maturation estimated by the radiographic method. Ann. WAU Vet. Med., 18: 79-89.

Botsoglou N. A., Christaki E., Fletouris D.J., Florou-Paneri P., B.Spais A. 2002. The effect of dietary oregano essential oil on lipid oxidation in raw and cooked chicken during refrigerated storage. Meat Sci., 62: 259-265.

Botsoglou N. A., Christaki E., Florou-Paneri P., Giannenas I., G. Papageorgiou, and A. B. Spais, 2004. The effect of a mixture of herbal essential oils or L-tocopheryl acetate on performance parameters and oxidation of body lipid in broilers. South African J. Anim. Sci., 34: 52-61.

CRAIG W.J. 1999. Health-promoting properties of common herbs. Amer. J. Clin. Nutr., 70: suppl. 3: 491-499.

Crespo R., Stover S. M., Droual R., Chin R.P., Shivaprasad H.L. 1999. Femoral fractures in a young male turkey breeder flock. Avian Dis., 43: 150-154.

Crespo R., Stover S.M., Taylor K.T., Chin R.P., Shivaprasad H.L. 2000. Morphometric and mechanical properties of femora in young adult male turkeys with and without femoral fracturesa. Poult. Sci., 79: 602-608. 
Cross D.E., Hillman K., Fenlon D., Deans S.G., McDevitt R.M., Acamovic T., Stewart C.S., Pennycott T.W. 2004. Antibacterial properties of phytochemicals in aromatic plants in poultry diets. Poisonous Plants and Related Toxins, 18: 175-180.

Demir E., Sarica S., Ozcan M.A., Suicmez M. 2005. The use of natural feed additives as alternative to an antibiotic growth promoter in broiler diets. Arch. Geflügelk., 69: 110-116.

Donoghue D. J. 2003. Antibiotic residues in poultry tissues and eggs: human health concerns. Poutl. Sci., 82: 618-621.

Ferretti J. L., Capozza R. F., Mondelo N., E. Montuori, and J. R. Zanchetta 1993. Determination of femur structural properties by geometric and material variables as a function of body weight in rats. Evidence of sexual dimorphism. Bone, 14: 256-270.

Fritz Z., Schleicher A., Kinal S. 1993. Effect of substituting milfoil, St. Johnswort and lovage for antibiotics on chicken performance and meat quality. J. Anim. Feed Sci., 4: 189-195.

Guo F.C., Savelkoul H.F.J., Kwakkel R.P., Williams B.A., Verstegen M.W.A. 2003. Immunoactive, medicinal properties of mushroom and herb polysaccharides and their potential use in chicken diets. World's Poult. Sci. J., 59: 427-440.

Guo F.C., Kwakkel R.P., Williams B.A., Parmentier H.K., Li W. K., Yang Z.Q., Verstegen M.W.A. 2004. Effects of mushroom and herb polysaccharides on cellular and humoral immune responses of Eimeria tenella-infected chickens. Poult. Sci., 83: 1124-1132.

Heaney R. P. 1996. Bone mass, nutrition, and other lifestyle factors. Nutr. Rev., 54: S3-10.

Hota R.K., Dehuri P.K., Mishra P.K., Rao A.G., Behura P.C. 2000. Prophylactic and therapeutic efficacy of herbal "Animon" to control chronic respiratory disease in broilers. Phytomedica, 21: 61-69.

Janocha A., Osek M., Klocek B., Milczarek A., WasiŁowski Z. 2004. The influence of the protein content and Hy D premix on production effects and quality of bones in broiler chickens. Rocz. Nauk. Zoot., 20: 181-184. (in Polish, abstract in English)

Kalorey D.R., Kurkure N.V., Ramgaonkar J.S., Sakhare P.S., Warke S., Nigot N. K. 2005. Effect of polyherbal feed supplement "Growell" during induced aflatoxicosis, ochratoxicosis and combined mycotoxicoses in broilers. Asian-Australasian J. Anim. Sci., 18: 375-383.

KRAWCZYK J., Wє̨̇̇K S., CyWA-BenKo K. 2000. Kształtowanie się minimalnych cen produktów drobiowych o podwyższonej jakości [Minimal prices of enhanced quality poultry products]. Rocz. Nauk. Zoot., 7: 24-28. (in Polish)

KwIEcień M. 1997. Effectiveness of different levels of $\mathrm{Ca}, \mathrm{P}$ and $\mathrm{Na}$ on ossification process in broiler chickens. $\mathrm{PhD}$ dissertation, AR Lublin, Poland. (in Polish)

KwIECIEŃ M. 1999. Effectiveness of different levels of calcium, phosphorus and natrum on ossification process in broiler chickens. II. Investigations on Starbro chickens. Ann. UMCS, 47: 369-374. (in Polish, abstract in English)

KWIECIEŃ M. 2003. The effect of mineral nutrition on physical characteristics of bones of Isa Vedette and Starbro broiler chicken. Ann. UMCS, 69: 121-126.

KwIECIEN M. 2005. The influence of hulless barley on selected physical and chemical parameters in broiler chicken femur bones. J. Anim. Feed Sci., 14: 463-466.

Kwiecień M., Winiarska-Mieczan A. 2007. Effect of herbal addition to feed mixtures on mechanical and chemical parameters of the broiler chicken femoral bone. Pol. J. Environ. Stud., 16(3A): 179-184.

Mitsch P., Zitterl-Eglseer K., Kohler B., Gabler C., Losa R., Zimpernik I. 2004. The effect of two different blends of essential oil components on the proliferation of Clostridium perfringens in the intestines of broiler chickens. Poult. Sci., 83: 669-675.

Nageswara A.R., Reddy V.R., SRILAtha C.H. 1999. Effect of Livol Classic on the performance of commercial broilers fed aflatoxin. Phytomedica, 20: 65-70. 
Pisarski R.K., Kwiecień M. 2003. The effect of hullless oatos and barley upon the chemical composition and durability of broiler chickens tibia bones. Ann. UMCS, 21(81): 215-221. (in Polish, abstract in English)

Rath N.C., Balog J.M., Huff W.E., Huff G.R., Kulkarni G.B., Tierce J.F. 1999. Comparative differences in the composition and biochemical properties of tibiae of seven-and seventy-two-week-old male and female broiler breeder chickens. Poult. Sci., 78: 1232-1032.

Rath N.C., Huff G.R., Huff W.E., BaloG J.M. 2000. Factors regulating bone maturity and strength in poultry. Poult. Sci., 79: 1024-1032.

SeEman E. 1999. The structural basis of bone fragility in men. Bone, 25: 143-147.

Szeremeta J., Bochno R., Murawska D. 2005. Effects of type, age and sex of chickens on the physical and mechanical properties and mineral composition of leg bones. Pol. J. Natur. Sci., 18: 94-103.

StatSoft Inc. 1995. Statistica for Windows. Tulsa: StatSoft.

ŚLIWA E., RADZKI R. 1995. The resistance and resilience changes in the limb bones of broiler chickens during the first 10 weeks of life. Med. Wet., 51: 287-289. (in Polish, abstract in English)

Zimnoch L., Szarek J., AвcZaK J., Konwicki A. 2000. Effects of feed supplements on morphological pattern of internal organs in broiler chickens. Zesz. Nauk. PTZ Prz. Hod., 49: 65-76. (in Polish, abstract in English)

ZioŁecki J., Donuchowski W. 1989. Metoda oceny wartości rzeźnej drobiu [Slaughter value assessment methods]. Eds. COBRD, Poznań. (in Polish) 
